\title{
Remembering a fallen giant
}

\section{Honouring the life and sacrifice of a young RAAF doctor}

n 6 February 2015, a group of family and friends gathered at the Australian War Memorial for a Last Post ceremony to remember the life and sacrifice of Royal Australian Air Force (RAAF) medical officer, Squadron Leader Paul McCarthy. Paul died in the Sea King helicopter disaster in 2005 while on a humanitarian mission to Indonesia.

Paul, a 1997 graduate in medicine from the University of Queensland, received undergraduate sponsorship from the RAAF. After completing his residency in Nambour, he undertook officer training at RAAF Base Williams at Point Cook in Victoria, before serving as a senior medical officer at RAAF Base Pearce in Western Australia. He saw overseas service in Kyrgyzstan and East Timor. In response to the 2004 Boxing Day tsunami, he was part of the Australian Defence Force medical team in Banda Aceh. After only 3 days back in Australia, he returned to Indonesia on HMAS Kanimbla following the 2005 Sumatra earthquake. While approaching the island of Nias, a mechanical failure caused the helicopter to crash, killing nine servicemen and women, including Paul.

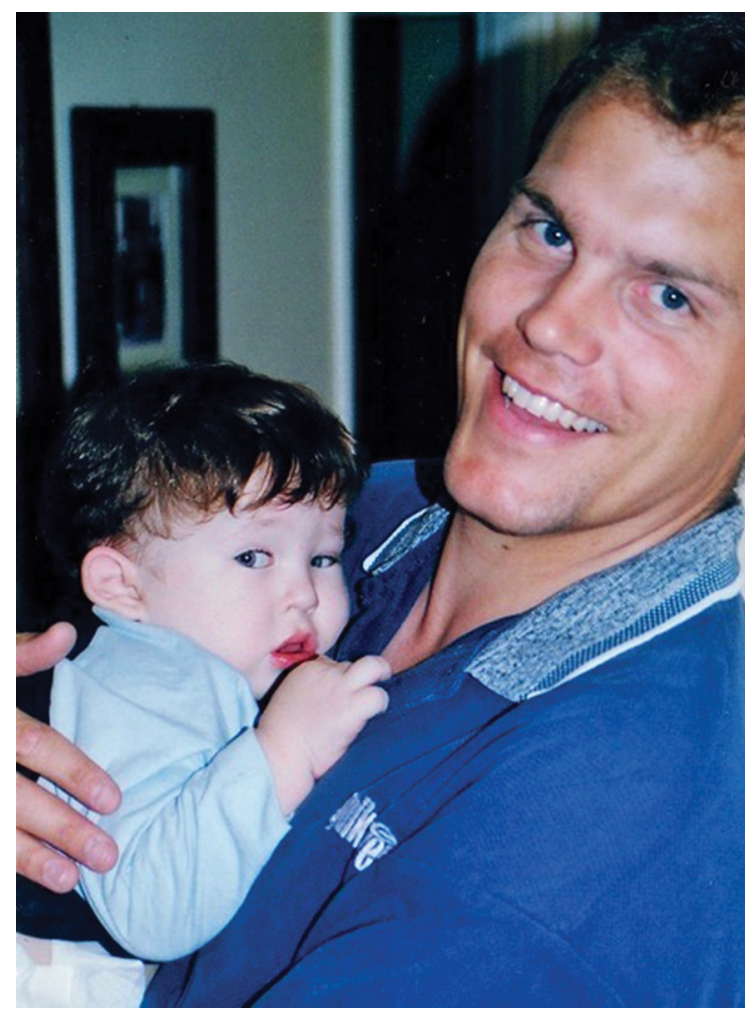

Paul McCarthy with his godson Lachlan Weinrauch.

Reproduced with permission.

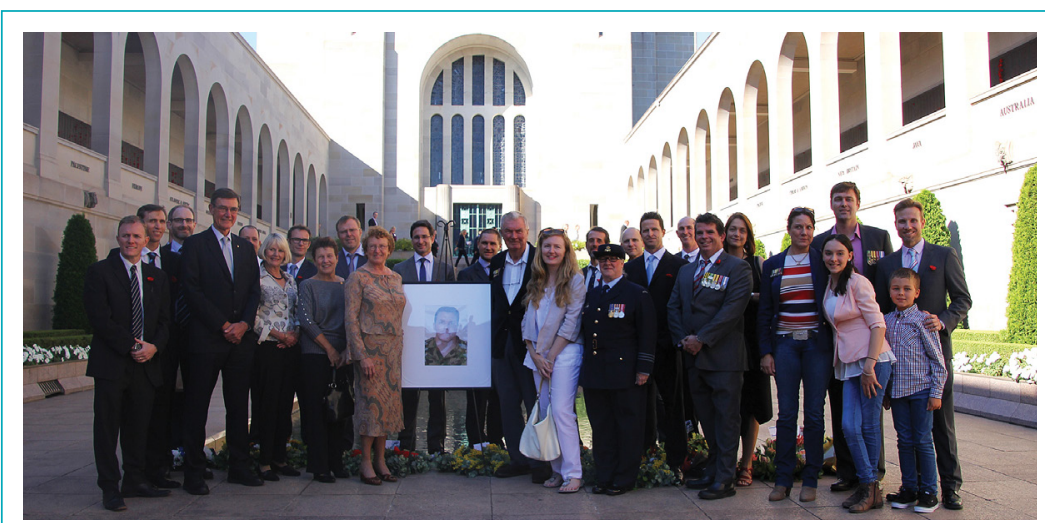

The Last Post ceremony for Paul at the Australian War Memorial, February 2015. Reproduced with permission.

"[Paul] was part of something much bigger

than just himself"

Andrew Burke MBBS, FRACP, DTMH

The Prince Charles Hospital, Brisbane, QLD.

andrew.burke@ health.qld.gov.au

doi: 10.5694/mjal5.00456
Much has been rightly made of Paul's sporting prowess. A number of us had the privilege of rowing surf boats with Paul for the Alexandra Headland Surf Life Saving Club while we were at university. Graduation saw the dispersal of our medical students' crew; however, Paul went onto bigger things, winning the 1999 Australian Surf Boat Open Championship title rowing for Coolum Beach Surf Life Saving Club. In the 2001 Atlantic Rowing Race, Paul rowed $4700 \mathrm{~km}$ across the Atlantic Ocean with Brisbane orthopaedic surgeon Patrick Weinrauch.

Paul's imposing stature belied his humour, gentle nature and enthusiasm for a life led at full pace. He was a man quick to laugh and a great friend to many people.

For those of us who do not serve in uniform, it is easy to take the defence force for granted and to forget the many sacrifices that serving members and their families make. Like medicine, it is a vocation ultimately centred on service to others. Seeing Paul's name etched in the Roll of Honour at the Australian War Memorial brought home how he was part of something much bigger than just himself.

As the Last Post was played for Paul, we thought of our son, brother and friend, his qualities and his great love of life. No doubt many, like me, also reflected on the friendships that our medical school years had forged and that had remained strong despite the passing of time.

We thank Paul for his generosity in life and acknowledge the ongoing sacrifice of his parents Haila and John, sister Annie and brother David. We will not forget.

(c) 2015 AMPCo Pty Ltd. Produced with Elsevier B.V. All rights reserved. 